\title{
ANNOUNCEMENT
}

\section{CFP: Women-only Special Issue of Religious Studies}

In spite of the fact that some of the most interesting work in philosophy of religion is being done by women, philosophy of religion remains a male-dominated subject. Last year, fewer than $8 \%$ of submissions to Religious Studies, the foremost philosophy of religion journal, were by women.

In view of this, we are inviting women to submit papers for a women-only Special Issue of Religious Studies on any area of philosophy of religion to highlight the excellent work being done by women in the field.

Each submission should be no more than 8,000 words, and papers should be submitted via the Religious Studies portal by $30^{\text {th }}$ September 2022. 'Women' is to be understood trans-inclusively. All papers will be anonymously and rigorously peer-reviewed in the same way as all Religious Studies submissions. We anticipate that the Special Issue will be published in Autumn or Winter 2023.

For further enquiries, please contact Dr Tasia Scrutton (t.scrutton@leeds.ac.uk). 